DOI: 10.18276/sip.2018.52/3-15

\title{
Malgorzata Wesołowska*
}

Uniwersytet Ekonomiczny w Krakowie Wydział Ekonomii i Stosunków Międzynarodowych

\section{PRZESTRZENNE ZRÓŻNICOWANIE PŁAC W POLSKICH WOJEWÓDZTWACH W LATACH 1999-2015**}

\begin{abstract}
Streszczenie
Celem artykułu jest dokonanie statystycznej analizy determinant (stopy bezrobocia, wydajności pracy) mających wpływ na przestrzenne zróżnicowanie płac w polskich województwach w latach 1999-2015. Analiza została przeprowadzona na gruncie kompilacji modeli płac efektywnościowych typu Solowa-Summersa oraz neoklasycznych modeli wzrostu gospodarczego. W rezultacie badań dowiedziono istotnej statystycznie dodatniej zależności pomiędzy wzrostem wydajności pracy oraz wzrostem poziomu płac. Na poziomie województw nie udało się jednak dowieść istnienia istotnie statystycznie ujemnej zależności pomiędzy wysokością stóp bezrobocia a płacami w badanym okresie.

Słowa kluczowe: zróżnicowanie płac, bezrobocie, wydajność, województwa

*Adres e-mail: malgorzata.wesolowska@uek.krakow.pl.

** Publikacja została sfinansowana ze środków MNiSW przyznanych Wydziałowi Ekonomii i Stosunków Międzynarodowych Uniwersytetu Ekonomicznego w Krakowie na badania dla młodych naukowców oraz uczestników studiów doktoranckich.
\end{abstract}




\section{Wprowadzenie}

Praca obok kapitału to jeden z najważniejszych zasobów, jakimi dysponuje gospodarka (Abel, Bernanke, Croushore, 2017, s. 99). Płaca otrzymywana za pracę odgrywa istotną rolę $\mathrm{w}$ kształtowaniu się relacji pomiędzy popytem a podażą na rynku pracy (Buchelt, Kubica, Łukasiewicz, Purgał-Popiela, 2014, s. 39-41). Na poziomie organizacji płaca (wynagrodzenie) spełnia następujące funkcje: dochodową, kosztową, motywacyjną i społeczną (Pocztowski, 2008, s. 329). Ponadto płace stanowią główny składnik dochodów rozporządzalnych gospodarstw domowych, wobec czego wszelkie ich zmiany prowadzą nie tylko do zmian samej wielkości dochodów, lecz także często prowadzą do zmian o charakterze społecznym czy politycznym (Szopa, 2005, s. 162).

Przeciwieństwem pracy w gospodarce jest bezrobocie, które w ujęciu mikroekonomicznym może mieć pozytywny wpływ na rynek pracy m.in. poprzez wzrost konkurencji o miejsca pracy czy poprawę efektywności gospodarowania. Z kolei najważniejszym negatywnym skutkiem na poziomie makroekonomicznym jest zmniejszenie poziomu produkcji z powodu niepełnego wykorzystania zasobu pracy, a w dłuższym okresie zmniejszenie dynamiki wzrostu produkcji w całej gospodarce (Kwiatkowski, 2002, s. 78-80; Mankiw, 2000).

Uzasadnieniem badań rynku pracy z uwagi na przestrzeń (obszar) może być występująca heterogeniczność popytu na tym rynku, mogąca skutkować brakiem odpowiednio wykwalifikowanych pracowników w bliskim otoczeniu firmy (Pocztowski, Miś, 2000, s. 112). Jak wskazuje Romer (2000), płaca realna nie wydaje się silnie procykliczna. Przesunięcia w popycie na siłę roboczą prowadzą do znacznych zmian w zatrudnieniu, ale tylko niewielkich w płacy realnej. Rynek pracy charakteryzuje się znacznie wolniejszymi dostosowaniami, niż ma to miejsce na innych rynkach (Begg, Vernasca, Fischer, Dornbusch, 2014, s. 368). Wyniki badań empirycznych potwierdzają istnienie znaczących różnic w poziomie płac pomiędzy różnymi gałęziami gospodarki, jak również pomiędzy różnymi grupami wielkości przedsiębiorstw (Mortensen, 2012, s. 16).

Celem opracowania jest próba analizy statystycznej determinant mających wpływ na przestrzenne zróżnicowanie płac w polskich województwach w latach 
1999-2015². Podstawą analiz jest model łączący modele płac efektywnościowych Solowa-Summersa oraz neoklasyczne modele wzrostu gospodarczego, w których poziom płac względnych jest zależny od wysokości stóp bezrobocia oraz względnej wydajności pracy. W dalszej części zostaną zaprezentowane graficzne i opisowe analizy przestrzennego zróżnicowania płac, wydajności pracy, stóp bezrobocia oraz statystyczna analiza współzależności występowania analizowanych zmiennych.

\section{Zróżnicowanie płac, wydajności pracy i stóp bezrobocia}

Pierwszym etapem części empirycznej pracy jest zbadanie zróżnicowania wysokości płac względnych, wydajności względnych oraz stóp bezrobocia w polskich województwach w latach 1999-2015. Względny poziom płac w danym województwie został policzony jako relacja wysokości płac ${ }^{2} \mathrm{w} i$-tym województwie dla $t$-tego roku do średniej wysokości płac dla całej gospodarki w $t$-tym roku. Podobnie została policzona względna wydajność pracy ${ }^{3}$ jako relacja poziomu wydajności pracy w $i$-tym województwie dla $t$-tego roku do średniej wysokości wydajności względnej dla całej gospodarki w $t$-tym roku. Stopy bezrobocia stanowią wyrażoną w procentach wysokość bezrobocia rejestrowanego ${ }^{4}$.

${ }^{1}$ Wybór tego przedziału czasu wynikał z maksymalnej dostępności danych statystycznych na poziomie województw według podziału administracyjnego z $1999 \mathrm{r}$.

2 Przeciętne miesięczne wynagrodzenia brutto w zł bez wynagrodzeń pracowników w jednostkach budżetowych prowadzących działalność w zakresie obrony narodowej i bezpieczeństwa publicznego.

3 Wydajność pracy została policzona jako stosunek produkcji sprzedanej przemysłu w cenach bieżących w mln zł (dane nieostateczne do 2003 r. włącznie) do liczby pracujących (stan na dzień 31.12.2003) w tys. według faktycznego miejsca pracy; poza jednostkami budżetowymi prowadzącymi działalność w zakresie obrony narodowej i bezpieczeństwa publicznego; od 2002 r. dane opracowano z uwzględnieniem pracujących $\mathrm{w}$ gospodarstwach indywidualnych $\mathrm{w}$ rolnictwie przy wykorzystaniu wyników Narodowego Spisu Powszechnego Ludności i Mieszkań 2002 według stanu w dniu 20.05.2002.

${ }^{4}$ Stan na 31.12.2002; do 2002 r. do wyliczeń przyjęto liczbę pracujących uwzględniającą pracujących w gospodarstwach indywidualnych w rolnictwie wyszacowanych przy uwzględnieniu wyników Powszechnego Spisu Rolnego 1996, a od 2003 r. przy uwzględnieniu wyników Narodowego Spisu Powszechnego Ludności i Mieszkań 2002 oraz Powszechnego Spisu Rolnego 2002. 
Dokonując analizy zróżnicowania płac ${ }^{5}$ (rys. 1), można wysnuć następujące wnioski: wśród szesnastu polskich województw jedno z nich, województwo mazowieckie, charakteryzowało się znacznie wyższym od przeciętnego poziomem płac (136\%); województwa, które również osiągnęły wyższy niż przeciętny poziom płacy, to śląskie (111\%), dolnośląskie (106\%) oraz pomorskie (105\%); w trzeciej grupie znajdują się województwa reprezentujące najbardziej przeciętne wartości płacy: małopolskie (99\%), wielkopolskie (99\%), opolskie (97\%), zachodniopomorskie (97\%); województwa o nieco niższej wartości płac w porównaniu do średniej w gospodarce to: lubelskie (95\%), łódzkie (95\%) i podlaskie (95\%); najniższy poziom płac był notowany w województwach: świętokrzyskim (94\%), kujawsko-pomorskim (93\%), lubuskim (93\%), podkarpackim (92\%) i warmińsko-mazurskim (92\%).

Rysunek 1. Zróżnicowanie płac w województwach w latach 1999-2015 (Polska=100)

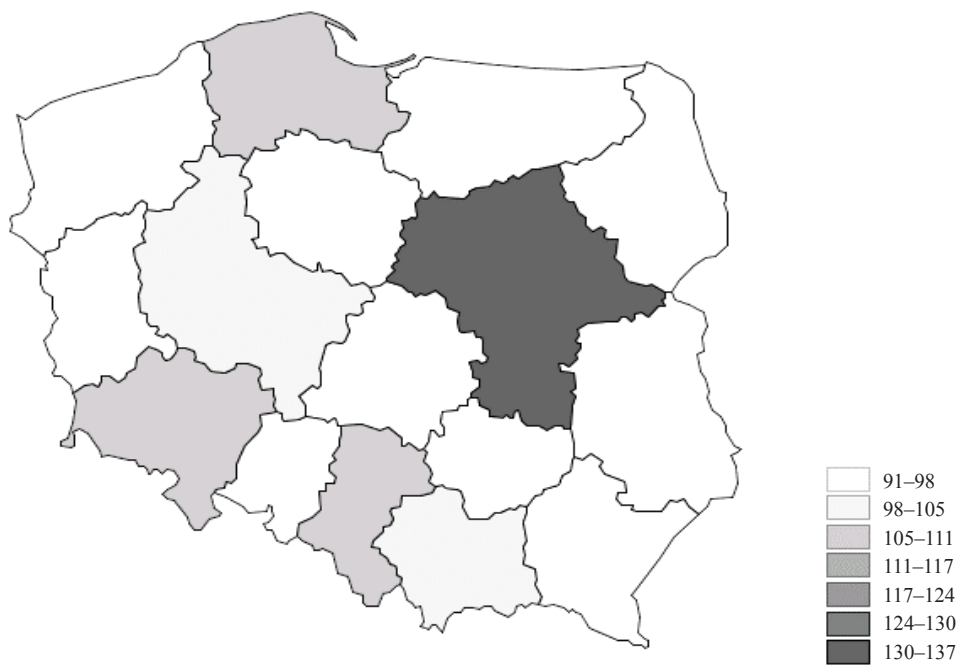

Źródło: opracowanie własne na podstawie danych GUS.

${ }^{5}$ Zróżnicowanie to obliczono w następujący sposób: najpierw dla każdego roku t $=1999,2001$, ..., 2015 obliczono płace względne, rozumiane jako relacja wynagrodzeń w danym województwie do wynagrodzeń w skali całej gospodarki. Następnie tak policzone płace względne uśredniono (średnią arytmetyczną) dla lat 1999-2015. 
Dokonując analizy zróżnicowania wydajności ${ }^{6}$ (rys. 2), można wysnuć następujące wnioski: najwyższe poziomy wydajności pracy zanotowało pięć województw: śląskie (163\%), mazowieckie (139\%), pomorskie (131\%), dolnośląskie (127\%) oraz wielkopolskie (126\%); do województw o zbliżonym do średniego poziomie wydajności pracy należą: lubuskie (107\%), opolskie (105\%), kujawsko-pomorskie (100\%), łódzkie (90\%) oraz zachodniopomorskie (90\%); z kolei najniższą średnią wartością wydajności pracy charakteryzowały się województwa: małopolskie (85\%), warmińsko-mazurskie (85\%), świętokrzyskie (70\%), podkarpackie (69\%), podlaskie $(63 \%)$, a także lubelskie (49\%).

Rysunek 2. Zróżnicowanie wydajności pracy w latach 1999-2015 (Polska = 100)

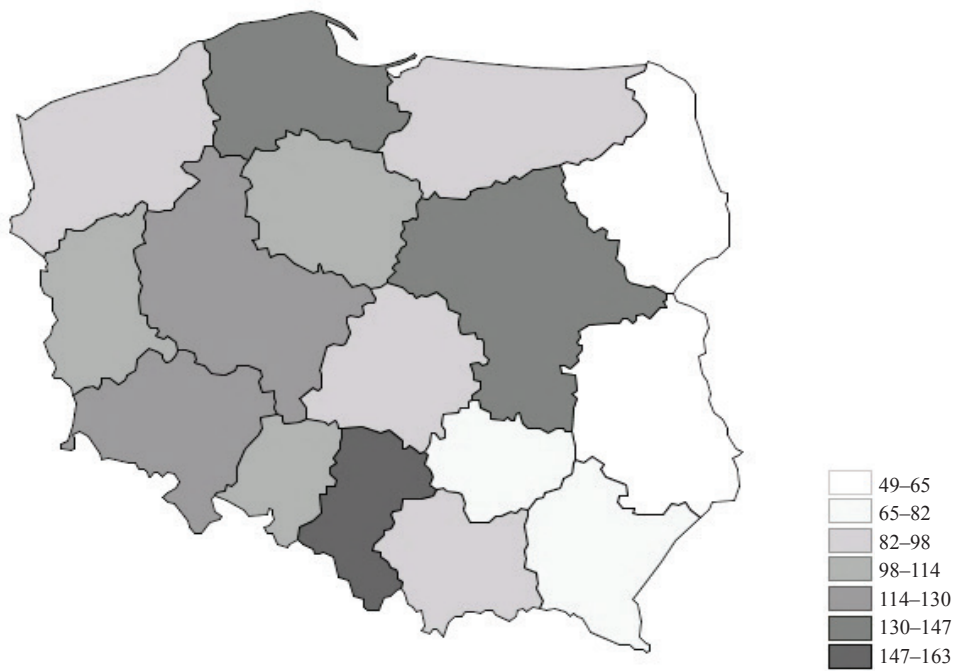

Źródło: opracowanie własne na podstawie danych GUS.

Dokonując analizy zróżnicowania stóp bezrobocia ${ }^{7}$ (rys. 3), można stwierdzić, że województwami, które charakteryzowały się najwyższymi wartościami stóp bezrobocia, były: warmińsko-mazurskie (149\%), zachodniopomorskie (130\%), kujawsko-pomorskie (120\%) oraz lubuskie (119\%); do województw o średnim poziomie stóp bezrobocia należały: świętokrzyskie (109\%), podkarpackie (105\%),

${ }^{6}$ Zróżnicowanie to policzono analogicznie do zróżnicowania płac.

${ }^{7}$ Zróżnicowanie to policzono analogicznie do zróżnicowania płac. 
dolnośląskie (102\%), opolskie (97\%), pomorskie (96\%), łódzkie (95\%), lubelskie (93\%) i podlaskie (89\%); z kolei najniższe wartości stóp bezrobocia osiągnęły województwa: śląskie (78\%), małopolskie (74\%), mazowieckie (72\%) i wielkopolskie $(72 \%)$.

Rysunek 3. Zróżnicowanie stóp bezrobocia w latach 1999-2015 (Polska = 100)

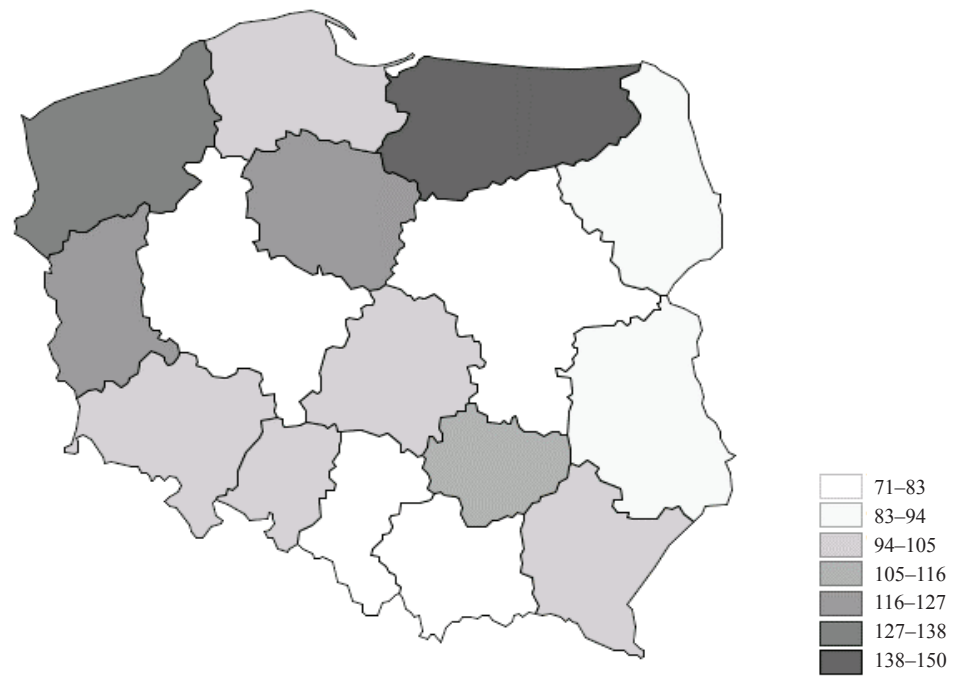

Źródło: opracowanie własne na podstawie danych GUS

\section{Zróżnicowanie stóp bezrobocia i wydajności pracy a zróżnicowanie płac - próba analizy statystycznej}

W tej części pracy zostaną zaprezentowane wyniki analizy wpływu stóp bezrobocia oraz względnej wydajności pracy na płace względne we wszystkich polskich województwach w latach 1999-2015. Analiza przebiegała dwuetapowo. Najpierw policzono współczynnik korelacji pomiędzy płacami względnymi a odpowiednio stopami bezrobocia i wydajnością względną, co pozwoliło na stwierdzenie zachodzenia pewnych współzależności wśród obserwowanych zjawisk. Następnie dokonano oszacowania parametrów równań regresji, w których stopa bezrobocia 
i względna wydajność pracy objaśnia płace względne na podstawie próby przekrojowo-czasowej złożonej ze wszystkich szesnastu województw.

Na rysunku 4 przedstawiono relację, jaka zachodzi pomiędzy wielkością płac względnych a wysokością stóp bezrobocia $\mathrm{w}$ województwach $\mathrm{w}$ przyjętym okresie czasu. $\mathrm{Z}$ analizy wynika, że w większości obserwacji wyższa stopa bezrobocia współwystępowała z niższym poziomem płac względnych. Potwierdza to również wartość współczynnika korelacji, który dla tych zmiennych wynosi -0,35.

Rysunek 4. Relacja płac względnych do stóp bezrobocia w latach 1999-2015

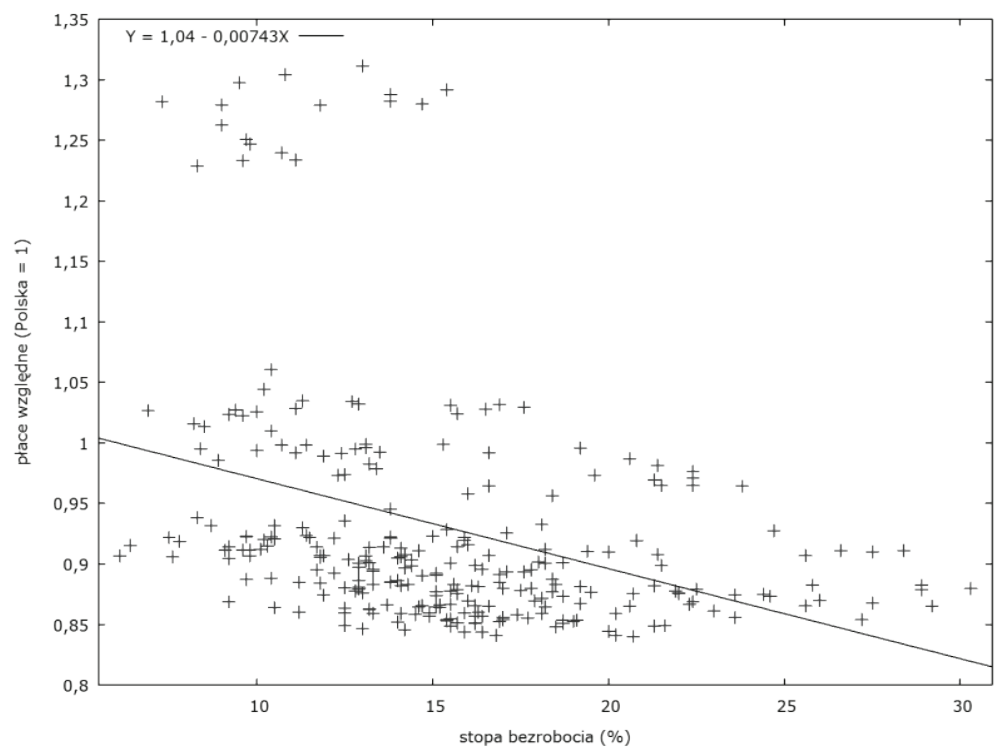

Źródło: opracowanie własne na podstawie danych GUS.

Na rysunku 5 przedstawiono relację, jaka zachodzi pomiędzy wielkością płac względnych a wydajnością względną w województwach w przyjętym okresie czasu. $\mathrm{Z}$ analizy wynika, że z reguły w tych województwach, w których wydajność pracy była wyższa, wyższa była także płaca względna. Potwierdza to również wartość współczynnik korelacji, który dla tych zmiennych wynosi 0,65 . 
Rysunek 5. Relacja płac względnych do wydajności względnej w latach 1999-2015

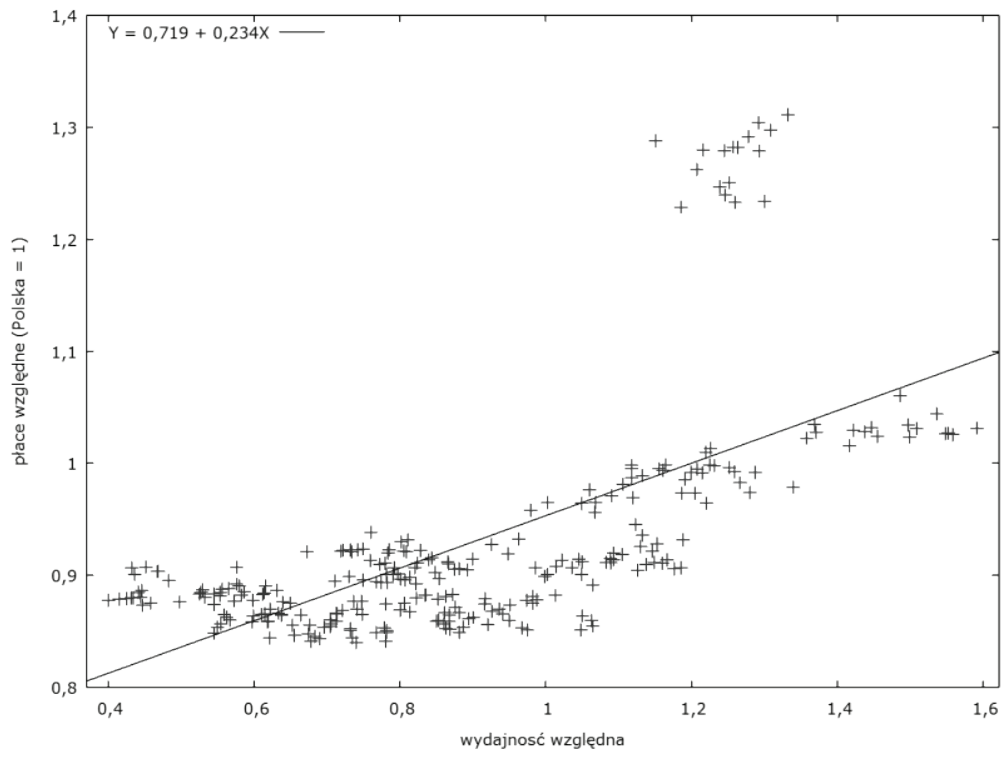

Źródło: opracowanie własne na podstawie danych GUS.

Na rysunkach 4 i 5 wyraźnie widać grupę obserwacji znacznie różniących się od pozostałych. Na podstawie analizy danych statystycznych stwierdzono, że wszystkie te obserwacje należą do województwa mazowieckiego. Biorąc pod uwagę także wartości, jakie to województwo prezentuje w zróżnicowaniu płac, wydajności i stóp bezrobocia, do dalszych analiz posłużono się nim jako województwem bazowym.

W drugim etapie statystycznej analizy oszacowano parametry równania, które jest kompilacją modeli płac efektywnościowych (Solow, 1979; Summers, 1988) z długookresowymi, neoklasycznymi modelami wzrostu gospodarczego (Mankiw, Romer, Weil, 1992; Nonneman, Vanhoudt, 1996; Solow, 1956). Równanie prezentuje się następująco:

$$
\bar{w}_{i t}=a_{0}-a_{1} u_{i t}+a_{2} \bar{y}_{i t}
$$

gdzie $a_{0}>0, \frac{a_{1}}{a_{0}}=b>0$, parametr $a_{1}<0$ opisuje wpływ stopy bezrobocia $\left(u_{i t}\right)$ na płace względne $\left(\bar{w}_{i t}\right)$, z kolei parametr $a_{2}>0$ opisuje wpływ względnej wydajności pracy $\left(\bar{y}_{i t}\right)$ na płace względne $\left(\bar{w}_{i t}\right)$. 
Dokładniejsze analizy oddziaływania stóp bezrobocia i względnej wydajności na płace względne można uzyskać poprzez dodanie do równania (1) efektu dywersyfikacji stałej. Po uwzględnieniu tego efektu równanie (2) prezentuje się następująco:

$$
\bar{w}_{i t}=a_{0}-a_{1} u_{i t}+a_{2} \bar{y}_{i t}+\sum_{j=1}^{15} B_{j} d_{j}
$$

gdzie parametry $a_{0}, a_{1}, a_{2}$ oraz zmienne $\bar{w}_{i t}, u_{i t}, \bar{y}_{i t}$ interpretuje się tak samo jak w równaniu (1), $d_{j}$ jest zmienną zero-jedynkową dla $j$-tego województwa niebazowego, a parametr $B_{j}$ opisuje procentową różnicę, która przy takiej samej stopie bezrobocia $u$ i takiej samej względnej wydajności pracy $\bar{y}$ wystąpiłaby pomiędzy przeciętnym poziomem płac względnych $\mathrm{w} j$-tym województwie a województwem bazowym (mazowieckim).

Oszacowane parametry obu równań dla próby przekrojowo-czasowej złożonej ze wszystkich szesnastu województw przedstawione są w tabeli $1 . \mathrm{Z}$ analiz tych można wyciągnąc następujące wnioski: po pierwsze, z oszacowań parametrów obu powyższych równań płynie wniosek, że poziom płac względnych był istotnie statystycznie powiązany z wydajnością względną $(\bar{y})$ na poziomie istotności $1 \%$. Oszacowane równanie (1) wskazuje, że wraz ze wzrostem wydajności względnej o 1 punkt procentowy następuje wzrost płacy względnej o około 0,22 . Innymi słowy, aby płaca względna wzrosła o około 2 punkty procentowe, wydajność względna musi wzrosnąć o 10 punktów procentowych. Z kolei oszacowanie równania (2) wskazuje, że wzrost względnej wydajności pracy o 1 punkt procentowy powodował wzrost płac względnych o 0,07 punktu procentowego. Ta zależność jest zgodna z teoretycznymi tezami i dotychczasowymi wynikami badań, które potwierdzają, że poziom płac jest determinowany przez wydajność pracy.

Tabela 1. Oszacowane parametry równania (1 i 2 ) dla polskich województw

\begin{tabular}{|l|c|c|}
\hline \multicolumn{1}{|c|}{ Zmienna objaśniająca } & Równanie 1 & Równanie 2 \\
\hline \multicolumn{1}{|c|}{1} & 2 & 3 \\
\hline \multirow{2}{*}{ Stała } & 0,804301 & 1,17424 \\
& {$[0,000]$} & {$[0,000]$} \\
\hline \multirow{2}{*}{ Dolnośląskie } & - & $-0,278499$ \\
& - & {$[0,000]$} \\
\hline \multirow{2}{*}{ Kujawsko-pomorskie } & $-0,379396$ \\
\end{tabular}




\begin{tabular}{|c|c|c|}
\hline 1 & 2 & 3 \\
\hline Lubelskie & - & $\begin{array}{c}-0,324397 \\
{[0,000]}\end{array}$ \\
\hline Lubuskie & - & $\begin{array}{c}-0,389909 \\
{[0,000]}\end{array}$ \\
\hline Łódzkie & - & $\begin{array}{c}-0,35504 \\
{[0,000]}\end{array}$ \\
\hline Małopolskie & - & $\begin{array}{c}-0,311486 \\
{[0,000]}\end{array}$ \\
\hline Opolskie & - & $\begin{array}{c}-0,342858 \\
{[0,000]}\end{array}$ \\
\hline Podkarpackie & - & $\begin{array}{c}-0,371593 \\
0,000]\end{array}$ \\
\hline Podlaskie & - & $\begin{array}{c}-0,337072 \\
{[0,000]}\end{array}$ \\
\hline Pomorskie & - & $\begin{array}{c}-0,285608 \\
{[0,000]}\end{array}$ \\
\hline Śląskie & - & $\begin{array}{c}-0,255852 \\
{[0,000]}\end{array}$ \\
\hline Świętokrzyskie & - & $\begin{array}{c}-0,354679 \\
{[0,000]}\end{array}$ \\
\hline Warmińsko-mazurskie & - & $\begin{array}{c}-0,380613 \\
{[0,000]}\end{array}$ \\
\hline Wielkopolskie & - & $\begin{array}{c}-0,344207 \\
{[0,000]}\end{array}$ \\
\hline Zachodniopomorskie & - & $\begin{array}{l}-0,335 \\
{[0,000]}\end{array}$ \\
\hline $\bar{y}$ & $\begin{array}{c}0,216391 \\
{[0,000]}\end{array}$ & $\begin{array}{c}0,0731458 \\
{[0,000]}\end{array}$ \\
\hline $\mathrm{u}$ & $\begin{array}{c}-0,00449361 \\
{[0,000]}\end{array}$ & $\begin{array}{c}0,000358811 \\
{[0,092]}\end{array}$ \\
\hline $\mathrm{R}^{2}$ & 0,456030 & 0,986383 \\
\hline Skor. $\mathrm{R}^{2}$ & 0,451986 & 0,985472 \\
\hline Liczba obserwacji & \multicolumn{2}{|c|}{272} \\
\hline
\end{tabular}

$R^{2}$ to współczynnik determinacji, skor. $R^{2}$ to skorygowany współczynnik determinacji. W nawiasach kwadratowych pod estymatorami podano empiryczny poziom istotności (wartość $p$ ) oszacowanych parametrów.

Źródło: opracowanie własne.

Po drugie, z oszacowania równania (1) wynika, że stopa bezrobocia wykazuje istotny (na poziomie istotności 1\%), choć słaby wpływ na płace względne. Oszacowana wartość wskazuje, że wraz ze wzrostem bezrobocia o 1 punkt procentowy następuje spadek poziomu płac względnych o 0,004 . Z kolei oszacowanie równania (2) sugeruje, że poziom płac względnych w województwach był słabo istotnie 
statystycznie zależny od wysokości stóp bezrobocia (poziom istotności 10\%); co więcej, wykazuje on wartość dodatnią, co jest sprzeczne z teoretycznymi założeniami oraz wynikami badań (Adamczyk, Tokarski, Włodarczyk, 2009; Tokarski, 2012), które potwierdzają, że poziom płac jest determinowany przez poziom bezrobocia występującego w gospodarce.

Po trzecie, we wszystkich województwach efekt dywersyfikacji stałej okazał się istotny statystycznie na poziomie istotności 1\%. Wśród województw, które najmniej się różnią od bazowego, można wskazać: śląskie, dolnośląskie i pomorskie. Województwa średnio (przeciętnie) różniące się od województwa bazowego to: lubelskie, łódzkie, małopolskie, opolskie, podlaskie, świętokrzyskie, wielkopolskie, zachodniopomorskie. Z kolei województwa najbardziej różniące się od bazowego to: kujawsko-pomorskie, lubuskie, podkarpackie i warmińsko-mazurskie.

Po czwarte, równanie (1), bez dywersyfikacji stałej, objaśnia kształtowanie się płac względnych w polskich województwach w około $45,2 \%$, natomiast równanie (2) w około $98,5 \%$.

\section{Wnioski}

Na podstawie przeprowadzonych analiz można wyciągnąć następujące wnioski:

1. Prosty model teoretyczny, który został wykorzystany do analizy przestrzennego zróżnicowania płac w polskich województwach dla okresu 1999-2015, zakłada, że wraz ze wzrostem poziomu wydajności pracy oraz spadkiem bezrobocia powinien rosnać poziom płac. Zostało to potwierdzone w obu przypadkach w stosunku do wydajności pracy. Jednak w odniesieniu do stóp bezrobocia tylko jedno równanie, pierwsze, potwierdziło tę zależność. Po uwzględnieniu w modelu dywersyfikacji stałej wykazał on przeciwną (dodatnią) zależność, jednak na słabym poziomie istotności.

2. Biorąc pod uwagę zróżnicowanie poziomu płac w województwach, można podać, że ich najwyższy poziom był w województwie mazowieckim, a następnie w śląskim, dolnośląskim i pomorskim. W dużej mierze wynika to z lokalizacji w tych województwach centrów regionalnego rozwoju gospodarczego, przemysłu górniczego czy wydobywczego (województwo śląskie i dolnośląskie), a także 
przemysłu stoczniowego (województwo pomorskie). Najniższe wartości płac były w województwach podkarpackim i warmińsko-mazurskim.

3. Zestawiając ze sobą zróżnicowanie wydajności pracy, można stwierdzić, że ich najwyższe wartości osiągały te same województwa co w przypadku płac oraz jeszcze województwo wielkopolskie. $Z$ kolei najniższe wartości notowały województwa podlaskie i lubelskie.

4. W odniesieniu do zróżnicowania stóp bezrobocia województwo warmińsko-mazurskie, zachodniopomorskie, kujawsko-pomorskie oraz lubuskie charakteryzowały się największymi wielkościami w badanym okresie. Natomiast województwa o najniższym poziomie stóp bezrobocia to: mazowieckie, wielkopolskie, małopolskie i śląskie.

5. Przeprowadzone analizy sugerują, że na poziomie województw w badanym okresie nie wszystkie badane cechy wykazują wyraźny podział na słabszą Polskę Wschodnią (Polskę B) oraz lepiej rozwiniętą Polskę Środkowo-Zachodnią (Polskę A). W największym stopniu jest to widoczne przy przestrzennym zróżnicowaniu wysokości stóp bezrobocia, w którym najwyższe wartości występowały w północno-zachodniej części Polski. Natomiast w odniesieniu do wydajności pracy i poziomu płac $\mathrm{w}$ większości najsłabsze wartości charakteryzowały rolnicze województwa wschodnie.

\section{Podsumowanie}

Analizy rynku pracy powinny towarzyszyć możliwie każdej decyzji podejmowanej we współczesnej gospodarce. Z uwagi na fakt, że przeprowadzone analizy dotyczyły województw, płynące wnioski mogą służyć władzom rządowym, samorządowym, analitykom czy badaczom do lepszego dopasowywania polityk i narzędzi kształtujących otoczenie społeczno-gospodarcze. W celu uzyskania większej liczby danych zasadne wydaje się kontynuowanie badań dla węższych przedziałów czasu czy konkretnych podregionów (grup województw bądź powiatów). 


\section{Bibliografia}

Abel, A.B., Bernanke, B.S., Croushore, D. (2017). Macroeconomics. New York: Pearson.

Adamczyk, A., Tokarski, T., Włodarczyk, R.W. (2009). Przestrzenne zróżnicowanie płac w Polsce. Gospodarka Narodowa, 9, 87-108.

Begg, D., Vernasca, G., Fischer, S., Dornbusch, R. (2014). Mikroekonomia. Warszawa: PWE. Buchelt, B., Kubica, I., Łukasiewicz, G., Purgał-Popiela, J. (2014). Gospodarowanie kapitałem ludzkim. Kraków: Wydawnictwo Uniwersytetu Ekonomicznego w Krakowie.

Kwiatkowski, E. (2002). Bezrobocie. Podstawy teoretyczne. Warszawa: Wydawnictwo Naukowe PWN.

Mankiw, N.G. (2000). Macroeconomics. New York: Worth Publishers.

Mankiw, N.G., Romer, D., Weil, D.N. (1992). A Contribution to the Empirics of Economic Growth. Quarterly Journal of Economics, 2 (107), 407-437.

Mortensen, D.T. (2012). Dyspersja płac. Dlaczego podobni pracownicy zarabiają różnie? Warszawa: PWE.

Nonneman, W., Vanhoudt, P. (1996). A Further Augmentation of the Solow Model and the Empirics of Economic Growth for the OECD Countries. Quarterly Journal of Economics, 111, 943-953.

Pocztowski, A. (2008). Zarzadzanie zasobami ludzkimi. Strategie-procesy-metody. Warszawa: PWE.

Pocztowski, A., Miś, A. (2000). Analiza zasobów ludzkich w organizacji. Kraków: Wydawnictwo Akademii Ekonomicznej w Krakowie.

Romer, D. (2000). Makroekonomia dla zaawansowanych. Warszawa: Wydawnictwo Naukowe PWN.

Solow, R.M. (1956). A Contribution to the Theory of Economic Growth. Quarterly Journal of Economics, 70, 65-94.

Solow, R.M. (1979). Another Possible Sources of Wage Stickiness. Journal of Macroeconomics, 1, 79-82.

Summers, L.H. (1988). Relative Wages, Efficiency Wages, and Keynesian Unemployment. American Economic Review, 78, 383-388.

Szopa, B. (2005). Zmiany dochodów ludności w Polsce na tle uwarunkowań systemowych. Kraków: Wydawnictwo Akademii Ekonomicznej w Krakowie.

Tokarski, T. (2012). Przestrzenne zróżnicowanie płac w polskich powiatach. Studia Prawno-Ekonomiczne, 85, 287-308. 


\title{
REGIONAL WAGE DIFFERENCES IN POLAND IN THE YEARS 1999-2015
}

\begin{abstract}
The aim of the article is to do a statistical analysis of the determinants of wage differences (unemployment rate, labor productivity) in Polish voivodships in years 1999-2015. The analysis was based on compilation of Solow-Summers' efficiency-wage models and neoclassical models of economic growth. As a result of the research, a statistically significant positive relationship was discovered between the increase in relative work efficiency and the increase in the relative level of wages. At the voivodships level, however, it was not possible to prove the existence of a statistically significant negative relationship between the level of unemployment rates and relative wages in the analysed period.
\end{abstract}

Keywords: wages differences, unemployment, labor productivity, voivodships

JEL codes: C23, E24, J31 